\title{
DROUGHT REDUCES ROOT RESPIRATION IN SUGAR MAPLE FORESTS
}

\author{
Andrew J. Burton, ${ }^{1}$ Kurt S. Pregitzer, ${ }^{1}$ Gregory P. ZogG, ${ }^{2}$ And Donald R. ZaK ${ }^{2}$ \\ ${ }^{1}$ School of Forestry and Wood Products, Michigan Technological University, Houghton, Michigan 49931 USA \\ ${ }^{2}$ School of Natural Resources and the Environment, University of Michigan, Ann Arbor, Michigan 48109-1115 USA
}

\begin{abstract}
Soil moisture deficits can reduce root respiration, but the effects have yet to be quantified at the stand level or included in models of forest carbon budgets. We studied fine-root ( $\leq 1.0 \mathrm{~mm}$ diameter) respiration in four sugar maple forests for three growing seasons in order to assess the combined effects of temperature, $\mathrm{N}$ concentration, and soil moisture on respiration rates. Fine-root respiration at the four sites was exponentially related to soil temperature and linearly related to root $\mathrm{N}$ concentration and soil moisture availability. Most of the variability in respiration rates was explained by temperature. Differences in soil moisture availability explained temporal variation within sites in respiration rate at a given temperature, whereas differences among sites in respiration rates resulted from sitespecific differences in fine-root $\mathrm{N}$ concentration. Periodic moisture deficits during 1995 and 1996 were sufficient to cause declines of up to $17 \%$ in total growing-season root respiration at affected sites. Estimated reductions in respiration of up to $0.8 \mathrm{Mg} \mathrm{C} /$ ha during dry years were equivalent to a significant portion of annual aboveground woody biomass $\mathrm{C}$ increment, arguing for the inclusion of soil moisture availability as a predictor of root respiration when modeling $\mathrm{C}$ allocation in forest ecosystems.
\end{abstract}

Key words: Acer saccharum; carbon allocation; drought; nitrogen concentration; root respiration; soil moisture; soil temperature; stand level respiration; sugar maple.

\section{INTRODUCTION}

Understanding the influence of environmental factors on the amount of carbon allocated below ground is critical if the effects of climate change on forest carbon balance are to be modeled realistically. Without such knowledge, tree growth and survival cannot be accurately forecast for future climates. Much of the $\mathrm{C}$ allocated below ground is lost to root respiration, which can consume $8-52 \%$ of daily carbohydrate production from photosynthesis (Pate et al. 1979, Lambers 1987, Buwalda 1993, Lambers et al. 1996). Global-change scenarios typically predict changes in soil temperature, $\mathrm{N}$ availability, and moisture (Pastor and Post 1988, Aber et al. 1989, Houghton and Woodwell 1989, Mintzer 1990), all of which may impact root respiration and, thus, alter forest $\mathrm{C}$ balance. Advances have been made in understanding and modeling the effects of temperature and $\mathrm{N}$ concentration on root respiration (Lawrence and Oechel 1983, Ryan 1991b, Burton et al. 1996, Ryan et al. 1996, Zogg et al. 1996), and it also is known that soil moisture deficits can reduce root respiration (Vartanian and Chauveau 1986, Palta and Nobel 1989a, $b$, Hall et al. 1990, Gansert 1994). However, the effects of soil moisture have yet to be quantified at the forest stand level, and it is unclear how drought conditions might affect the responses of root respiration to temperature and $\mathrm{N}$.

Water stress can reduce photosynthetic C assimilation by plants (Bradford and Hsiao 1982, Hanson and

Manuscript received 11 June 1997; revised 20 November 1997; accepted 21 November 1997.
Hitz 1982); hence, forest C models typically reduce gross primary productivity (GPP) during dry conditions (Running and Coughlan 1988, Ewel and Gholz 1991, Rastetter et al. 1991, Aber and Federer 1992, Nikolov and Fox 1994). Some models also alter the relative proportions of $\mathrm{C}$ allocated to leaves, stems, and roots (Running and Gower 1991) during moisture stress, or reduce the amount of $\mathrm{C}$ allocated for growth respiration as dry-matter production decreases (Nikolov and Fox 1994). To our knowledge, however, no models explicitly reduce root maintenance respiration as soil moisture deficits become severe. Predictions of tree growth and survival depend, in part, on the amount of $\mathrm{C}$ remaining after accounting for respiration (Running and Gower 1991, Aber and Federer 1992). If root maintenance respiration declines as soil moisture deficits occur, the resulting strain on $\mathrm{C}$ reserves will be less severe, possibly leading to a smaller reduction in growth and increased survival. A more complete understanding of the effects of soil moisture availability on root respiration is needed if such possibilities are to be assessed.

In 1994, we studied fine-root ( $\leq 1.0 \mathrm{~mm}$ diameter) respiration in four Michigan sugar maple (Acer saccharum Marsh.) forests to quantify the effects of temperature and fine-root $\mathrm{N}$ concentration on respiration in the absence of severe soil moisture deficits (Burton et al. 1996, Zogg et al. 1996). Measurements of fineroot respiration were continued during 1995 and 1996, years in which soil moisture deficits of varying degrees occurred at the sites. These data enabled us to examine the combined effects of temperature, $\mathrm{N}$ concentration, 
and soil moisture on fine-root respiration. Objectives were: (1) to determine if root respiration is influenced by soil moisture availability; (2) to develop predictive relationships for northern hardwood root respiration based on temperature, root $\mathrm{N}$ concentration, and soil matric potential; and (3) to assess the potential effects of moisture deficit on seasonal root respiration relative to stand level $\mathrm{C}$ budgets.

\section{Methods}

Root respiration was measured on excised fine roots collected from four sugar maple forests located along a $3^{\circ}$ latitudinal transect in Michigan. The forests are second-growth northern hardwoods, $\sim 85 \mathrm{yr}$ old, dominated by sugar maple, and occurring on sandy, welldrained Spodosols (Burton et al. 1991, MacDonald et al. 1991, Randlett et al. 1992). Six $30 \times 30$ m study plots are located at each site. Three of these plots are control plots and the others have received annual fertilizer applications of $30 \mathrm{~kg} \mathrm{NO}-\mathrm{N} / \mathrm{ha}$ since 1994 (Zogg et al. 1996). To date, the $\mathrm{NO}_{3}^{-}$additions have not altered root respiration or tissue $\mathrm{N}$ concentrations in the fertilized plots (Zogg et al. 1996; G. P. Zogg, unpublished data), so this report will not separate fertilized from control plots.

Samples for root respiration measurement were collected from $10 \mathrm{~m}$ wide buffer strips surrounding each plot. Soil cores (10 cm deep, $5.4 \mathrm{~cm}$ inner diameter) were collected from three random locations in each buffer strip. The cores were transported to nearby field labs ( $<1 \mathrm{~h}$ travel time per site), and were composited on a plot basis. All fine ( $\leq 1.0 \mathrm{~mm})$, nonwoody, live roots were sorted from each core and rinsed free of soil and organic matter with deionized water. Live roots were distinguished by white, cream, tan, or brown coloration and a smooth appearance. Dead roots were dark brown or black in color, were brittle, and had frayed, rough edges. Excess water was blotted from the root samples, and $0.5-\mathrm{g}$ (fresh mass) subsamples were wrapped in moistened tissue paper and used for respiration measurements. Respiration was measured as $\mathrm{O}_{2}$ consumption, using gas phase $\mathrm{O}_{2}$ electrodes (model LD 2/2 oxygen electrode, Hansatech Instruments, Norfolk, UK) connected to constant-temperature circulating-water baths (Burton et al. 1996, Zogg et al. 1996). Root samples were allowed to equilibrate to measurement temperature for $20 \mathrm{~min}$, after which $\mathrm{O}_{2}$ consumption was monitored for 40-60 min. Relative humidity inside the closed $\mathrm{O}_{2}$ consumption chambers was $100 \%$; thus, roots did not dehydrate during the measurement period. Three complete $\mathrm{O}_{2}$ electrode systems were run simultaneously, allowing measurements of respiration at $6^{\circ}, 18^{\circ}$, and $24^{\circ} \mathrm{C}$ to be completed within $3 \mathrm{~h}$ of sample collection. The ratio of respiration rates at $24^{\circ}$ and $6^{\circ} \mathrm{C}$ was used to calculate $Q_{10}$ values for the sites, using the equation presented by Spain (1982). Following respiration measurements, root subsamples were oven-dried $\left(65^{\circ} \mathrm{C}, 24 \mathrm{~h}\right)$ for determination of dry mass, ground, and analyzed for $\mathrm{N}$ using an elemental analyzer (Carlo Erba NA 1500 Series II, CE Elantech, Lakewood, New Jersey, USA).

Respiration measurements were made in early September, October, and November 1994; May, July, and September 1995; late June to early July 1996; and September 1996. Results presented as $\mathrm{O}_{2}$ consumption in this report can be converted to $\mathrm{CO}_{2}$ production using a respiratory quotient (RQ) of 0.8 . This value was determined during the May 1995 sampling by placing additional root samples in an $\mathrm{O}_{2}$ electrode chamber (at $24^{\circ} \mathrm{C}$ ) that was hooked in line with an infrared gas analyzer (IRGA, CIRAS-I portable gas analyzer, PP Systems, Haverhill, Massachusetts, USA), allowing simultaneous determination of $\mathrm{CO}_{2}$ production and $\mathrm{O}_{2}$ consumption. No differences in RQ existed among sites.

Root respiration can be sensitive to the $\left[\mathrm{CO}_{2}\right]$ at which measurements are made (Qi et al. 1994, Burton et al. 1997) and, thus, rates measured in the laboratory can differ from those that would occur at actual soil $\left[\mathrm{CO}_{2}\right]$ in the field. For our sites, we have found that root respiration declines as $\left[\mathrm{CO}_{2}\right]$ increases from 350 to $3000 \mu \mathrm{L} / \mathrm{L}$, with little addtional change in respiration rate at $\left[\mathrm{CO}_{2}\right]$ above $3000 \mu \mathrm{L} / \mathrm{L}$ (Burton et al. 1997). Using the equation presented by Burton et al. (1997), it can be determined that a correction factor of 1.16 is appropriate for adjusting the $\mathrm{O}_{2}$ consumption values in this paper (obtained at measurement $\left[\mathrm{CO}_{2}\right]$ of (4000$14000 \mu \mathrm{L} / \mathrm{L})$ to those that would occur at soil $\left[\mathrm{CO}_{2}\right]$ of $1200 \mu \mathrm{L} / \mathrm{L}$.

Soil matric potential at the sites was measured using gypsum blocks (Model 5201, Soilmoisture Equipment Corporation, Santa Barbara, California, USA). Single moisture blocks were located at depths of 15 and 75 $\mathrm{cm}$ at each plot. Soil temperature was measured using thermistors (Model ES-060-SW, Data Loggers, Logan, Utah, USA) buried at $15 \mathrm{~cm}$ in each plot. Moisture blocks and thermistors were read every $30 \mathrm{~min}$ by Omnidata EasyLoggers (Models 824 and 925, Data Loggers, Logan, Utah, USA), with average values recorded every $3 \mathrm{~h}$. Moisture block resistance readings (ohms) were converted to matric potential (megapascals) using relationships developed in the lab from moisture blocks placed in intact soil cores collected from the plots and equilibrated on soil moisture plates at potentials ranging from -0.01 to $-1.5 \mathrm{MPa}$.

ANOVA was used to compare root respiration among temperatures, sites, and sampling periods (Wilkinson 1990). Because respiration is exponentially related to temperature, the natural logarithm of respiration was used as the dependent variable in the ANOVA. Linear and nonlinear regression (Wilkinson 1990) were applied to assess the effects of temperature, root $\mathrm{N}$ concentration, and soil matric potential on respiration at the sites. Because soil moisture blocks can lag behind actual soil moisture, possible predictors for respiration included matric potential on the date of respiration 
TABLE 1. ANOVA of the effects of study site, temperature, and sampling period on fine-root respiration in four Michigan sugar maple forests $(n=576)$.

\begin{tabular}{lrrrr}
\hline \hline \multicolumn{1}{c}{ Source } & df & \multicolumn{1}{c}{ MS } & $F$ ratio & \multicolumn{1}{c}{$P$} \\
\hline Site & 3 & 0.88 & 16.7 & $<0.001$ \\
Temperature & 2 & 157.93 & 3019.4 & $<0.001$ \\
Sampling period & 7 & 0.95 & 18.2 & $<0.001$ \\
Site $\times$ Temperature & 6 & 0.04 & 0.8 & 0.606 \\
Site $\times$ Sampling period & 21 & 0.18 & 3.5 & $<0.001$ \\
Temperature $\times$ Sampling period & 14 & 0.15 & 2.9 & $<0.001$ \\
Site $\times$ Temperature $\times$ Sampling period & 42 & 0.09 & 1.7 & 0.008 \\
Error & 480 & 0.05 & & \\
\hline
\end{tabular}

measurement and during the first and second weeks following respiration measurement. Soil matric potential at $15 \mathrm{~cm}$ during the first week following respiration measurements was consistently most strongly correlated with observed respiration rates; thus, it was used as the indicator of soil moisture status in all regression analyses. Soil moisture data were indicative of the general moisture status of the study sites, not of the particular locations at which root samples were taken. Therefore, soil moisture data from individual plots were combined and site means $(n=4)$ for each sampling date $(n=8)$ and measurement temperature $(n=$ 3 ) were used in the regression analyses (total $n=96$ ).

\section{RESULTS}

Fine-root respiration differed significantly among sites and sampling dates (Table 1) and increased with temperature. Significant interactions also occurred (Table 1), suggesting variation among sites and sampling dates in the factors controlling respiration. An examination of the patterns among sites in root respiration, root $\mathrm{N}$ concentration, and soil moisture at each sampling date (Fig. 1) helps to explain these interactions. During sampling periods when moisture deficits did not occur (Fig. 1A, B, E), differences among sites in root respiration followed patterns among sites in fine-root $\mathrm{N}$ concentration, with Sites $\mathrm{B}$ and $\mathrm{C}$ having higher root
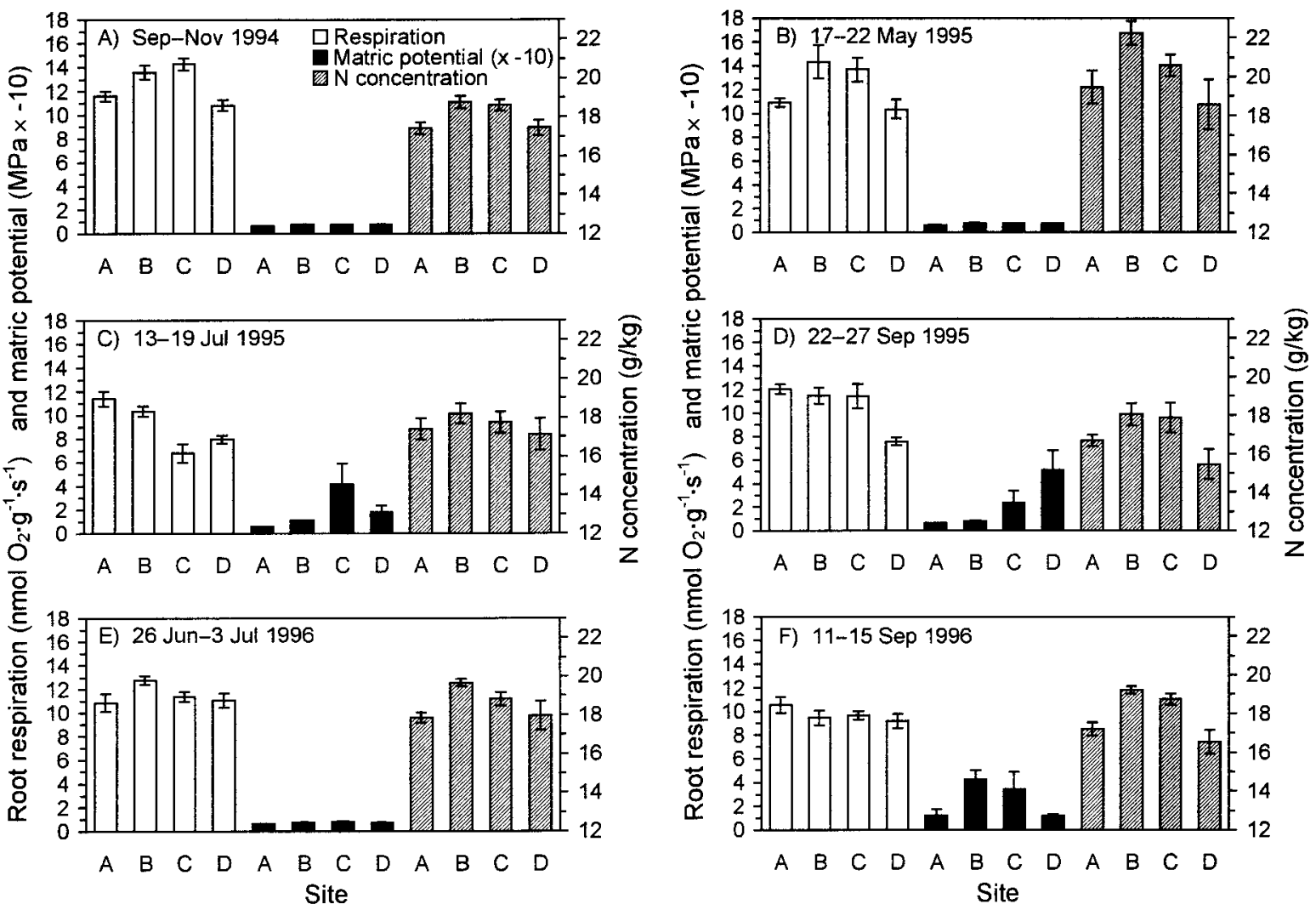

FIG. 1. Fine-root respiration (at $24^{\circ} \mathrm{C}$ ), soil matric potential, and fine-root $\mathrm{N}$ concentration in four Michigan sugar maple forests during six sampling periods. Matric potentials have been multiplied by -10 to facilitate comparision with respiration rates. Error bars indicate $\pm 1 \mathrm{SE}$. The Sep-Nov 1994 period (A) represents means across three separate samplings conducted during the same season in 1994. 
respiration and higher root $\mathrm{N}$ concentration than Sites $\mathrm{A}$ and D. In these nondrought sampling periods, there were always significant correlations between fine-root $\mathrm{N}$ concentration and respiration at $24^{\circ} \mathrm{C}(P<0.01)$ and $18^{\circ} \mathrm{C}(P<0.05)$, with weaker correlations at $6^{\circ} \mathrm{C}(P$ $<0.10)$. When drought occurred at one or more of the sites (Fig. 1C, D, F), N concentration and respiration were only occasionally correlated.

The occurrence of drought caused respiration rates at individual sites to be reduced to levels lower than those that would be predicted from fine-root $\mathrm{N}$ concentration and temperature (Fig. 1C, D, F). Within sites, respiration at $24^{\circ} \mathrm{C}$ was negatively correlated with soil matric potential $(P<0.05)$ for sites that experienced drought (Sites B, C, and D), but not for Site A, which experienced no moisture deficits during the three years of study. Interactions of site with sampling period in Table 1 reflect the fact that moisture deficits of similar intensity did not occur simultaneously at all sites.

Overall, there were no differences among sites in the effect of temperature on respiration (nonsignificant site $\times$ temperature interaction, Table 1$)$. Based on mean respiration rates at $6^{\circ}$ and $24^{\circ} \mathrm{C}$, the average $\mathrm{Q}_{10}$ across sites was 2.6. The interaction between time period and temperature (Table 1) suggests that the rate of increase in respiration with temperature $\left(\mathrm{Q}_{10}\right)$ was not the same for all time periods. It appears that this effect may be, in part, a consequence of moisture deficit, as the $\mathrm{Q}_{10}$ for respiration was between 2.5 and 3.0 for all sites and time periods except for Sites C and D in July 1995 and Site D in September 1995. These sites were experiencing strong moisture deficits during these times (Fig. 1C, D), and had $\mathrm{Q}_{10}$ 's for respiration of 2.1 to 2.2. However, not all sites experiencing moisture deficit had lower $\mathrm{Q}_{10}$ values. Moisture deficits at Sites B and C in September 1996 (Fig. 1F) did not result in lowered $Q_{10}$ for respiration $\left(Q_{10}=2.7\right.$ for both sites $)$.

Temperature, root $\mathrm{N}$ concentration, and soil matric potential were all significant predictors $(P<0.05)$ of root respiration in linear regression analyses. However, the best model for predicting fine-root respiration was a nonlinear model in which respiration was linearly related to $\mathrm{N}$ concentration and soil matric potential, and exponentially related to temperature:

$$
\begin{aligned}
& R_{\mathrm{O}_{2}}=(0.063 N+0.670 M) e^{0.098 T} \\
&\left(R^{2}=0.93, P<0.001, \mathrm{SEE}=1.08\right)
\end{aligned}
$$

where $R_{\mathrm{O}_{2}}$ is respiration in nanomoles of $\mathrm{O}_{2}$ per gram per second, $N$ is root nitrogen concentration in grams per kilogram, $M$ is soil matric potential in megapascals, and $T$ is soil temperature at $15 \mathrm{~cm}$. SEE is the standard error of the estimate. Eq. 1 can be modified to predict root respiration as $\mathrm{CO}_{2}$ production at soil $\left[\mathrm{CO}_{2}\right]$ by using the RQ (0.8) and correction factor for measurement $\left[\mathrm{CO}_{2}\right]$ effects (1.16) described in the Methods section, yielding the following expression:

$$
R_{\mathrm{CO}_{2}}=(0.058 N+0.622 M) e^{0.098 T}
$$

where $R_{\mathrm{CO}_{2}}$ is respiration in nanomoles of $\mathrm{CO}_{2}$ per gram per second.

It is possible that the moisture effect does not become important until soil matric potential reaches a certain threshold. Piecewise regression models were used to explore this possibility, but resulted in virtually no change in the predictive strength of the regression. They suggested a threshold matric potential of -0.08 $\mathrm{MPa}$, which is only slightly lower than values typically recorded for moist soils during the dormant season. A lack of information over the entire continuum from moist to dry soils in the current data set may have limited its utility for determining an exact threshold.

\section{DISCUSSION}

The observed decline in root respiration with increasing soil moisture deficit is consistent with reports that gradually applied moisture stress can cause reduced respiration in plant tissues (Wilson et al. 1980, Amthor and McCree 1990). In roots, such effects have been observed in herbaceous species (Vartanian and Chauveau 1986, Hall et al. 1990), desert succulents (Palta and Nobel 1989a, b), and tree saplings (Gansert 1994). The periodic moisture deficits that occurred during 1995 and 1996 at Sites B, C, and D were sufficient to cause overall declines in total growing-season root respiration. For example, estimated fine-root respiration at Site C for June through September 1995 was $17 \%$ less when soil moisture deficits were accounted for than when they were not (Fig. 2).

It could be questioned whether the declines in respiration that we measured on excised, rinsed roots are representative of those actually occurring in the field under drought conditions. We suspect that our laboratory procedure, in which roots were rehydrated during rinsing, resulted in measured reductions in respiration that were the same or less than those occurring in the field. Others have reported a return to normal respiration rates within $24-36 \mathrm{~h}$ after rewetting severely dehydrated roots (Vartanian and Chauveau 1986, Palta and Nobel 1989a, b), but these returns toward normal did not begin for several hours after rehydration. We completed our measurements within $3 \mathrm{~h}$ of sample collection and within $1.5 \mathrm{~h}$ of sample processing and rewetting. An examination of oxygen consumption rates over time during respiration measurement of moisture-stressed roots (Fig. 3) reveals no clear increasing trend suggestive of rapid rehydration effects. Additionally, it should be noted that total soil respiration at the study sites declined markedly during the same dry periods for which we measured reduced root respiration (G. P. Zogg, unpublished data). This would indicate that root respiration, microbial respiration, or both were impacted by soil moisture deficits. The respiration rates that we measured during nondrought periods are similar to those reported for freshly detached root mats of northern hardwoods in the field (Fahey and Hughes 1994), and we have found no dif- 
FIG. 2. Estimates of monthly fine-root respiration at Site $\mathrm{C}$ with and without accounting for soil moisture deficits. Eq. 1 was used to derive respiration estimates. A soil matric potential typical of moist conditions $(-0.07 \mathrm{MPa})$ was used for all months when estimating respiration without accounting for soil moisture effects.

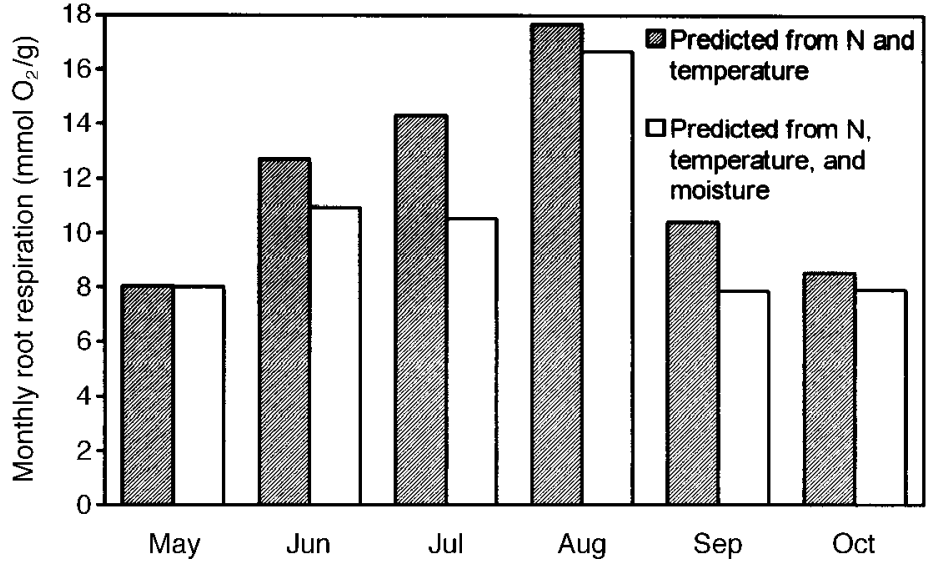

ference in respiration between attached and detached roots of small sugar maple seedlings and mature trees from the sites (A. J. Burton and G. P. Zogg, unpublished data). However, these comparisions were made with an IRGA immediately following root removal from the soil, and thus do not eliminate the possibility that respiration rates made in the lab, $3 \mathrm{~h}$ after excision, might differ from those in the field.

The $17 \%$ decline in root respiration illustrated in Fig. 2 represents only a small portion of annual GPP for these sites, but it still has an important impact on the overall $\mathrm{C}$ budget of the stand. Given a fine-root biomass of $\sim 7 \mathrm{Mg} /$ ha at Site C (Hendrick and Pregitzer 1993), and using the conversions from $\mathrm{O}_{2}$ consumption to $\mathrm{CO}_{2}$ production described in the Methods section, the reduction in respiration illustrated in Fig. 2 represents $\sim 0.8 \mathrm{Mg} \mathrm{C} /$ ha over the growing season. This is a significant proportion of the $2 \mathrm{Mg} \mathrm{C} / \mathrm{ha}$ in aboveground woody biomass increment measured at Site C in 1995 (A. J. Burton, unpublished data). Moreover, this value is higher than the $0.5 \mathrm{Mg} \mathrm{C} / \mathrm{ha}$ in aboveground woody increment measured at the site in 1989, a very dry year following a year of extremely heavy seed production

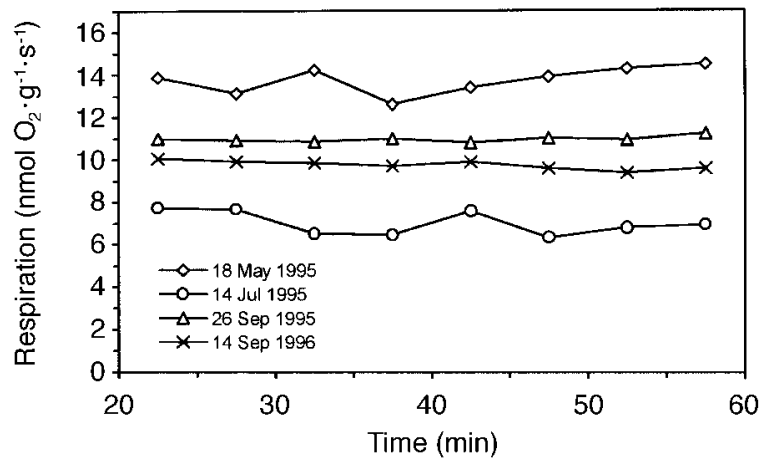

FIG. 3. Fine-root $\mathrm{O}_{2}$ consumption rates over time at $24^{\circ} \mathrm{C}$ for Site C during nondrought (18 May 1995) and moisturestressed conditions. Data points represent mean respiration rates of six plots for 5-min increments following an initial 20 -min period during which root samples equilibrated to the temperature inside the $\mathrm{O}_{2}$ consumption chamber (at $24^{\circ} \mathrm{C}$ ).
(D. D. Reed, unpublished data). Carbon balance models are of little utility if they cannot accurately predict annual aboveground increment. Thus, an error of 0.8 $\mathrm{Mg} \mathrm{C} /$ ha associated with ignoring reduced respiration during soil moisture deficits is potentially very significant. In models that use stored $\mathrm{C}$ reserves to assess the likelihood that a tree will survive stress events, such an error could result in erroneous estimates of both growth and survival.

For plant tissues in general, it is assumed that most of the reduction in total respiration during water stress results from decreased construction respiration (Hanson and Hitz 1982). However, this does not appear to be the case for the tree roots that we studied. It is known that root elongation decreases during periods of moisture stress (Teskey and Hinckley 1981, Kuhns et al. 1985), but reduced root growth alone cannot account for the declines in respiration that we observed during the more severe periods of soil moisture deficit at the sites. For example, using a mean fine-root production rate for Site $\mathrm{C}$ of $0.14 \mathrm{~g} \cdot \mathrm{g}^{-1} \cdot \mathrm{mo}^{-1}$ between June and September (calculated from the data of Hendrick and Pregitzer 1993), a construction respiration cost of 0.25 g CO$_{2}-\mathrm{C} / \mathrm{g} \mathrm{C}$ (Penning de Vries 1975, Ryan 1991a), and a root $\mathrm{C}$ concentration of $50 \%$ (A. J. Burton, unpublished data), monthly growth respiration is estimated to be $1.44 \mathrm{mmol} \mathrm{CO}_{2}-\mathrm{C} / \mathrm{g}$ (equivalent to 1.55 mmol $\mathrm{O}_{2} / \mathrm{g}$ under laboratory measurement conditions). Total elimination of this level of growth respiration is insufficient to explain the monthly declines in respiration occurring at Site C in June, July, and September of 1995 ( 1.8 to $3.8 \mathrm{mmol} \mathrm{O}_{2} / \mathrm{g}$; Fig. 2). Much of the reduction in respiration that we observed must be due to decreases in either maintenance respiration or respiration associated with ion uptake and transport processes.

Lower maintenance respiration could result from reduced overall metabolic activity (e.g., protein synthesis) associated with cell dessication (Amthor and McCree 1990). Low soil moisture content can decrease ion movement toward, and uptake by, plant root sys- 


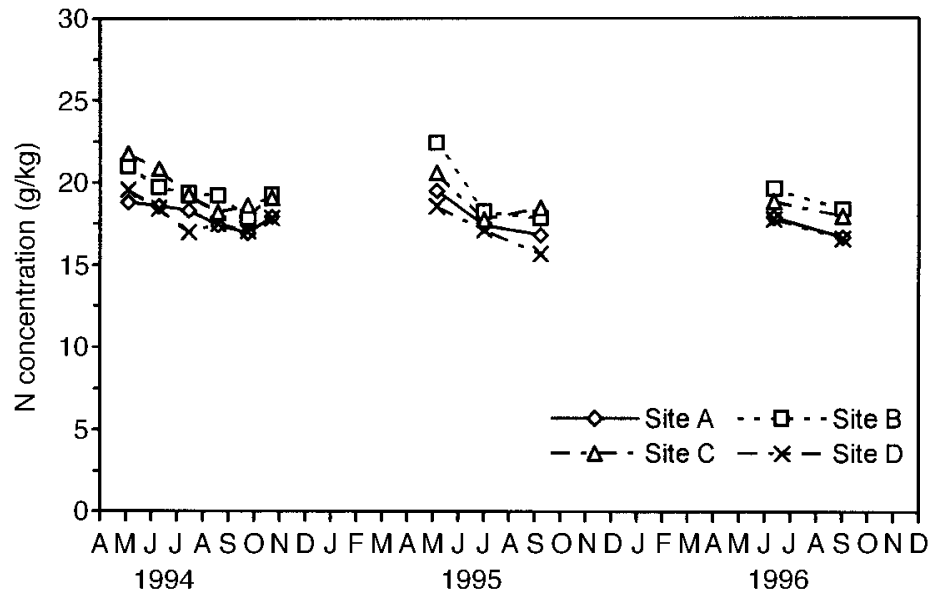

FIG. 4. Seasonal patterns in fine-root $\mathrm{N}$ concentration for 1994, 1995, and 1996. Fine-root $\mathrm{N}$ data for May, June, and July 1994 are those reported by Zogg et al. (1996).

tems (Bradford and Hsiao 1982, Jungk 1996), and can inhibit the rate at which nutrients are made available through mineralization (Dickinson and Pugh 1974). Short-term reductions in these processes during dry periods could lead to temporarily reduced respiratory requirements for ion uptake and nutrient transport. In roots of nonwoody species, ion uptake can represent a large portion of nongrowth respiration (Veen 1980, Lambers 1987, van der Werf et al. 1988, Poorter et al. 1991, Lambers et al. 1996). Consequently, much of the reduction in root respiration during periods of low soil moisture in such plants could be due to reduced ion uptake. Estimates of ion uptake respiration for woody species are sparse, but it appears that ion uptake respiration is a much lower proportion of total respiration (Buwalda 1993). Thus, it is likely that reduced respiration for ion uptake and nutrient transport is less important than reduced maintenance respiration in explaining the reduction in total respiration that we observed for sugar maple roots at low soil moisture contents.

An interesting observation during the study was the lower respiratory $\mathrm{Q}_{10}$ at Sites $\mathrm{C}$ and $\mathrm{D}$ during periods of moisture deficit in 1995. This reduction in $\mathrm{Q}_{10}$ may be indicative of differential effects of drought on the various components of total respiration. For instance, there could be a certain portion of maintenance respiration (e.g., basal respiration; Marshall and Perry 1986, Amthor 1989) that is less dependent on temperature than either growth or ion uptake respiration, and that must occur even during periods of drought. If this were the case, soil moisture deficits would reduce both total respiration and $Q_{10}$, as observed in 1995. Such a mechanism would be advantageous to the plant in that root tissues would remain viable during drought, and the $\mathrm{C}$ lost to respiration would be limited during excessively warm periods that often accompany moisture deficits.

Differences in soil moisture availability explained much of the temporal variation in respiration rate at a given temperature within sites, whereas differences among sites in respiration rates were due to site differences in fine-root $\mathrm{N}$ concentration. During nondrought sampling periods in this study, the highest respiration rates always occurred in fine roots having the highest $\mathrm{N}$ concentrations (Fig. 1). The cross-site relationship between fine-root $\mathrm{N}$ and respiration is in agreement with data previously reported for these sites (Burton et al. 1996, Zogg et al. 1996). In contrast to the between-site differences in fine-root $\mathrm{N}$ concentration, within-site seasonal differences in root $\mathrm{N}$ concentration were not reflected by corresponding changes in respiration rate. When only nondrought measurement periods were compared, there were no clear within-site seasonal differences in respiration rate, despite clear seasonal trends in fine-root $\mathrm{N}$ concentration (Fig. 4). The seasonal pattern in root $\mathrm{N}$ concentration within sites was characterized by high values in the spring, declining to lower levels in late summer and early fall, followed by slight increases in November. This pattern suggests storage and allocation of $\mathrm{N}$ for root growth, with the highest root $\mathrm{N}$ in the spring resulting from high levels of stored $\mathrm{N}$ just prior to rapid root and foliar growth. Overwinter storage of soluble (nonprotein) $\mathrm{N}$ has been reported for roots of several tree species (Tromp 1983, Millard and Proe 1991, 1992). As stored $\mathrm{N}$ is allocated to new growth in the spring and root biomass increases, root $\mathrm{N}$ concentration should decline, as we observed from May through October at the sites. If changes in the amount of stored $\mathrm{N}$ are responsible for the pattern illustrated in Fig. 4, and if respiration is controlled by the nonstored (primarily protein) portion of $\mathrm{N}$, then fine-root respiration within sites should be independent of the seasonal changes in $\mathrm{N}$ concentration associated with $\mathrm{N}$ storage and remobilization. This is in agreement with: (1) the relatively consistent respiration rates that we observed across seasons in nondrought time periods; and (2) the lack of withinsites temporal correlations between $\mathrm{N}$ concentration and respiration, despite the existence of significant correlations across sites between $\mathrm{N}$ concentration and respiration. 
Temperature, $\mathrm{N}$ concentration, and soil moisture availability were all significant predictors of fine-root respiration in the sugar maple forests studied. Although temperature alone was sufficient to explain most (90\%) of the observed variability in the respiration data, root $\mathrm{N}$ concentration and soil moisture potential explained significant portions of the remaining variation among sites and between sampling periods, respectively. Many ecosystem process models estimate root respiration based solely on soil temperature (Running and Gower 1991), and only a few recent efforts at modeling fineroot respiration have included both temperature and $\mathrm{N}$ concentration as predictors (Ryan 1991b, Ryan et al. 1996). To our knowledge, none of them have explicitly included soil moisture. Our results suggest that soil moisture potentials $\leq-0.2 \mathrm{MPa}$ can greatly reduce fine-root respiration. Over a growing season, soil moisture deficits can be sufficient to reduce root respiration by amounts that are significant relative to the amount of $\mathrm{C}$ allocated to the aboveground biomass increment. These findings argue for a better understanding of the influence of soil moisture on root respiration and for the explicit inclusion of soil moisture availability as a predictor of root respiration, as physiologically based models of forest $\mathrm{C}$ allocation become more advanced.

\section{ACKNOWLEDGMENTS}

The authors thank D. Rothstein, D. MacDonald, M. Laskowski, W. Williams, M. Piirainen, L. Bork, B. Woodring, J. Petriekas, and D. Mouradian for their assistance in the field and laboratory. We thank the USDA Forest Service and the University of Michigan Biological Station for providing access to field laboratories. This research was funded by the U.S. National Science Foundation (NSF Grants DEB 9221003, DEB 9629842, DBI 9413407) and the USDA Forest Service Northern Global Change Program. This paper has not been subject to review by the funding agencies and should not be construed to represent their policies.

\section{Literature Cited}

Aber, J. D., and C. A. Federer. 1992. A generalized, lumpedparameter model of photosynthesis, evapotranspiration, and net primary production in temperate and boreal forest ecosystems. Oecologia 92:463-474.

Aber, J. D., K. J. Nadelhoffer, and J. M. Melillo. 1989. Nitrogen saturation in northern forest ecosystems. BioScience 39:378-386.

Amthor, J. S. 1989. Respiration and crop productivity. Springer-Verlag, Berlin, Germany.

Amthor, J. S., and K. J. McCree. 1990. Carbon balance of stressed plants: a conceptual model for integrating research results. Pages 1-15 in R. G. Alscher and J. R. Cummings, editors. Stress responses in plants: adaptation and acclimation mechanisms. Wiley-Liss, New York, New York, USA.

Bradford, K. J., and T. C. Hsiao. 1982. Physiological responses to moderate water stress. Pages 263-324 in O. L. Lange, P. S. Nobel, C. B. Osmond, and H. Ziegler, editors. Physiological plant ecology. II. Water relations and carbon assimilation. Encyclopedia of plant physiology. New series, volume 12. Springer-Verlag, Berlin, Germany.

Burton, A. J., K. S. Pregitzer, G. P. Zogg, and D. R. Zak. 1996. Latitudinal variation in sugar maple fine root respiration. Canadian Journal of Forest Research 26:17611768.
Burton, A. J., C. W. Ramm, K. S. Pregitzer, and D. D. Reed. 1991. Use of multivariate methods in forest research site selection. Canadian Journal of Forest Research 21:15731580.

Burton, A. J., G. P. Zogg, K. S. Pregitzer, and D. R. Zak. 1997. Effects of measurement $\mathrm{CO}_{2}$ concentration on sugar maple root respiration. Tree Physiology 17:421-427.

Buwalda, J. G. 1993. The carbon costs of root systems of perennial fruit crops. Environmental and Experimental Botany 33:131-140.

Dickinson, C. H., and G. J. F. Pugh. 1974. Biology of plant litter decomposition. Academic Press, New York, New York, USA.

Ewel, K. C., and H. L. Gholz. 1991. A simulation model of the role of belowground dynamics in a Florida pine plantation. Forest Science 37:397-438.

Fahey, T. J., and J. W. Hughes. 1994. Fine root dynamics in a northern hardwood forest ecosystem, Hubbard Brook Experimental Forest, NH. Journal of Ecology 82:533-548.

Gansert, D. 1994. Root respiration and its importance for the carbon balance of beech saplings (Fagus sylvatica L.) in a montane beech forest. Plant and Soil 167:109-119.

Hall, A. J., D. J. Connor, and D. M. Whitfield. 1990. Root respiration during grain filling in sunflower: the effects of water stress. Plant and Soil 121:57-66.

Hanson, A. D., and W. D. Hitz. 1982. Metabolic responses of mesophytes to plant water deficits. Annual Review of Plant Physiology 33:163-203.

Hendrick, R. L., and K. S. Pregitzer. 1993. The dynamics of fine root length, biomass, and nitrogen content in two northern hardwood ecosystems. Canadian Journal of Forest Research 23:2507-2520.

Houghton, R. A., and G. M. Woodwell. 1989. Global climate change. Scientific American 260:36-44.

Jungk, A. O. 1996. Dynamics of nutrient movement at the soil-root interface. Pages 529-556 in Y. Waisel, A. Eshel, and U. Kafkafi, editors. Plant roots: the hidden half. Second edition. Marcel Dekker, New York, New York, USA.

Kuhns, M. R., H. E. Garrett, R. O. Teskey, and T. M. Hinckley. 1985. Root growth of black walnut trees related to soil temperature, soil water potential, and leaf water potential. Forest Science 31:617-629.

Lambers, H. 1987. Growth, respiration, exudation, and symbiotic associations: the fate of carbon translocated to roots. Pages 125-145 in P. J. Gregory, J. V. Lake, and D. A. Rose, editors. Root development and function. Cambridge University Press, Cambridge, UK.

Lambers, H., I. Scheurwater, and O. K. Atkin. 1996. Respiratory patterns in roots in relation to their functioning. Pages 323-362 in Y. Waisel, A. Eshel, and U. Kafkafi, editors. Plant roots: the hidden half. Second edition. Marcel Dekker, New York, New York, USA.

Lawrence, W. T., and W. C. Oechel. 1983. Effects of soil temperature on the carbon exchange of taiga seedlings. I. Root respiration. Canadian Journal of Forest Research 13: 840-849.

MacDonald, N. W., A. J. Burton, M. F. Jurgensen, J. W. McLaughlin, and G. D. Mroz. 1991. Variation in forest soil properties along a Great Lakes air pollution gradient. Soil Science Society of America Journal 55:1709-1715.

Marshall, J. D., and A. Perry. 1986. Basal and maintenance respiration of mycorrhizal and nonmycorrhizal root systems of conifers. Canadian Journal of Forest Research 17: 872-877.

Millard, P., and M. F. Proe. 1991. Leaf demography and seasonal internal cycling of nitrogen in sycamore (Acer pseudoplatanus L.) seedlings in relation to nitrogen supply. New Phytologist 117:587-596.

Millard, P., and M. F. Proe. 1992. Storage and internal cycling 
of nitrogen in relation to seasonal growth of Sitka spruce. Tree Physiology 10:33-43.

Mintzer, I. M. 1990. Energy, greenhouse gases, and climate change. Annual Review of Energy 15:513-550.

Nikolov, N. T., and D. G. Fox. 1994. A coupled carbonwater-energy-vegetation model to assess responses of temperate forest ecosystems to changes in climate and atmospheric $\mathrm{CO}_{2}$. Part I. Model concept. Environmental Pollution 83:251-262.

Palta, J. A., and P. S. Nobel. 1989a. Root respiration for Agave deserti: influence of temperature, water status, and root age on daily patterns. Journal of Experimental Botany 40:181-186.

Palta, J. A., and P. S. Nobel. 1989b. Influences of water status, temperature, and root age on daily patterns of root respiration for two cactus species. Annals of Botany 63: $651-662$

Pastor, J., and W. M. Post. 1988. Response of northern forests to $\mathrm{CO}_{2}$-induced climate change. Nature 334:55-58.

Pate, J. S., D. B. Layzell, and C. A. Atkins. 1979. Economy of carbon and nitrogen in a nodulated and nonnodulated ( $\mathrm{NO}_{3}$-grown) legume. Plant Physiology 64:1083-1088.

Penning de Vries, F. W. T. 1975. The cost of maintenance processes in plant cells. Annals of Botany 39:77-92.

Poorter, H., A. van der Werf, O. K. Atkin, and H. Lambers. 1991. Respiratory energy requirements of roots vary with the potential growth rate of a plant species. Physiologia Plantarum 83:469-475.

Qi, J., J. D. Marshall, and K. G. Mattson. 1994. High soil carbon dioxide concentrations inhibit root respiration of Douglas-fir. New Phytologist 128:435-442.

Randlett, D. L., D. R. Zak, and N. W. MacDonald. 1992. Sulfate adsorption and microbial immobilization in northern hardwood forests along an atmospheric deposition gradient. Canadian Journal of Forest Research 22:1843-1850.

Rastetter, E. B, M. G. Ryan, G. R. Shaver, J. M. Melillo, K. J. Nadelhoffer, J. E. Hobbie, and J. D. Aber. 1991. A general biogeochemical model describing the responses of the $\mathrm{C}$ and $\mathrm{N}$ cycles in terrestrial ecosystems to changes in $\mathrm{CO}_{2}$, climate, and $\mathrm{N}$ deposition. Tree Physiology 9:101126.

Running, S. W., and J. C. Coughlan. 1988. A general model of forest ecosystem processes for regional applications. I.
Hydrologic balance, canopy gas exchange, and primary production processes. Ecological Modelling 42:125-154.

Running, S. W., and S. T. Gower. 1991. FOREST-BGC, a general model of forest ecosystem processes for regional applications. II. Dynamic carbon allocation and nitrogen budgets. Tree Physiology 9:147-160.

Ryan, M. G. 1991a. Effects of climate change on plant respiration. Ecological Applications 1:157-167.

- 1991b. A simple method for estimating gross carbon budgets for vegetation in forest ecosystems. Tree Physiology 9:255-266.

Ryan, M. G., R. M. Hubbard, S. Pongracic, R. J. Raison, and R. E. McMurtrie. 1996. Foliage, fine-root, woody tissue, and stand respiration in Pinus radiata in relation to nitrogen status. Tree Physiology 16:333-343.

Spain, J. D. 1982. BASIC microcomputer models in biology. Addison-Wesley, Reading, Massachusetts, USA.

Teskey, R. O., and T. M. Hinckley. 1981. Influence of temperature and water potential on root growth of white oak. Physiologia Plantarum 52:363-369.

Tromp, J. 1983. Nutrient reserves in roots of fruit trees, in particular carbohydrates and nitrogen. Plant and Soil 71: 401-413.

van der Werf, A., A. Kooijman, and H. Lambers. 1988. Respiratory energy costs for the maintenance of biomass, for growth and for ion uptake in roots of Carex diandra and Carex acutiformis. Physiologia Plantarum 72:483-491.

Vartanian, N., and M. Chauveau. 1986. In vitro study of root respiration recovery following a drought stress period. Plant and Soil 92:255-264.

Veen, B. W. 1980. Energy costs of ion transport. Pages $187-$ 195 in D. W. Rains, R. C. Valentine, and A. Hollaender, editors. Genetic engineering of osmoregulation: impact on plant productivity for food, chemicals, and energy. Plenum Press, New York, New York, USA.

Wilkinson, L. 1990. SYSTAT: the system for statistics. SYSTAT, Evanston, Illinois, USA.

Wilson, D. R., C. H. M. van Bavel, and K. J. McCree. 1980. Carbon balance of water-deficient grain sorghum plants. Crop Science 20:153-159.

Zogg, G. P., D. R. Zak, A. J. Burton, and K. S. Pregitzer. 1996. Fine root respiration in northern hardwood forests in relation to temperature and nitrogen availability. Tree Physiology 16:719-725. 